Pastor, Peter. "Hajdu, Tibor and Ferenc Pollmann. 2014. A régi Magyarország utolsó háborúja 1914-1918 ('The Last War of Old Hungary 1914-1918'). Budapest: Osiris. 415 pp. With maps and photographs." Hungarian Cultural Studies. e-Journal of the American Hungarian Educators Association, Volume 9 (2016): http://ahea.pitt.edu DOI: 10.5195/ahea.2016.247

\title{
Hajdu, Tibor and Ferenc Pollmann. 2014. A régi Magyarország utolsó háborúja 1914-1918 ('The Last War of Old Hungary 1914- 1918'). Budapest: Osiris. 415 pp. With maps and photographs.
}

\author{
Reviewed by Peter Pastor, Montclair State University
}

There is a consensus among scholars that World War I represented a turning point in history. The Great War, as it was first called, was the first total war in modern history in which male civilians of the belligerent countries were mobilized to fight at the war front, while on the home front other civilians, male and female, were mobilized to supply the millions of troops with munitions and food.

German historians call the immense human and physical destruction caused by the warring armies using new technologies Die Urkatastrophe, the seminal catastrophe. During this conflict, industrial slaughter on the battlefield as well as repression and even genocide on the home front of the minorities also took place. The consequences of the war were equally farreaching. They led to the collapse of the four empires that participated in the war and power in general shifted from Europe to the United States. The dominant ideology of the prewar era, liberalism, went into a decline caused by the needs of a wartime command economy.

Authoritarian orthodox Marxism in the form of Bolshevism won a foothold in Russia and in the wake of the war another authoritarian ideology, fascism, won domination in Italy, offering a model to be imitated elsewhere. The hundredth anniversary of the outbreak of the war in 1914 was marked by the publication of a good number of new studies on World War I in the United States and in Europe. In Hungary translated works of foreign scholars and a few new monographs by Hungarian historians were published for the occasion. Of these, the most important is A régi Magyarország utolsó háborúja 1914-1918 authored by two prominent students of the era, the political and social historian Tibor Hajdu and the military historian Ferenc Pollmann.

Although the focus of the book, as the title suggests, is the role of Hungary alone in the conflict, this task is in fact accomplished by an examination of the activities of the AustroHungarian armies in the various theaters of the war. This could not have been done otherwise as "Old Hungary" was then still part of the Austro-Hungarian Monarchy that was created by the Compromise of 1867. The war front, therefore, was a common enterprise (28) where Austrian, Hungarian, and other nationality units were fighting against the enemy they faced. The western front, where fewer troops of the Habsburg Monarchy were engaged, is also examined in the book, and rightly so as the ebb and flow of the war there had a serious impact on the eastern, Balkan, and Italian fronts, where the Dual Monarchy carried out the lion's share of the fighting. While the book covers all the war fronts since they are interrelated, the authors have an easier task with the home front. Here they only detail the political, economic and social developments

$(\mathrm{cc}) \mathrm{BY}$

ULLS D-Serle
New articles in this journal are licensed under a Creative Commons Attribution 4.0 International License.

This journal is published by the University Library System of the University of Pittsburgh as part of its D-Scribe Digital Publishing Program and is cosponsored by the University of Pittsburgh Press 
Pastor, Peter. "Hajdu, Tibor and Ferenc Pollmann. 2014. A régi Magyarország utolsó háborúja 1914-1918 ('The Last War of Old Hungary 1914-1918'). Budapest: Osiris. 415 pp. With maps and photographs." Hungarian Cultural Studies. e-Journal of the American Hungarian Educators Association, Volume 9 (2016): http://ahea.pitt.edu DOI: 10.5195/ahea.2016.247

as they relate to Hungary. This narrow focus of the authors can be justified by the home rule Hungary had enjoyed since 1867.

Because of the immense consequences of the war, its causes and the question of responsibility for its outbreak loom large in historiography. The American historian John W. Langdon counts in his 1991 monograph, July 1914: The Long Debate, 1918-1990 (Oxford: Berg Publications), 25,000 books and articles in English alone on the origins of the war. Hajdu and Pollmann, as do most historians, do not give a unicausal explanation for the outbreak of the war and they also recognize that the controversy over the war's origins is often due to the selective marshaling of evidence (15). Their emphasis is on the turn-of-the-century Russian-supported Balkan nationalism and the formation of a bipolar alliance system of the great powers encompassing the Triple Alliance of Austria-Hungary, Germany and Italy on one side and the interlocking Triple Entente formed by France, Russia, and Great Britain on the other.

The Balkan Wars of 1912-1913 had the potential of leading into a great-power confrontation, but as Hajdu and Pollmann explain, "the Balkan powder keg" did not explode at that time because Russia, not yet ready for intervention, withheld support for the completion of the Serbian government's expansionist Greater Serbia project that was to include the South Slav areas of the Dual Monarchy (20). Serbia, however, did not abandon its goal and for this reason, as the authors note, a small country had the potential to trigger the outbreak of a big war (21). Nevertheless, the authors contend that the developments in the Balkans did not have a decisive role in the preparation and launching of the Great War (23). Rather, they attribute the war's outbreak to the bipolar alliance system, the war plans and the fatalism of the decision makers of the European great powers, who behaved like "sleepwalkers" (55) during the crisis month of July 1914.

The apt description of Europe's leaders as "sleepwalkers" comes, as the authors acknowledge, from Christopher Clark's 2012 blockbuster monograph The Sleepwalkers - How Europe Went to War in 1914. The authors' reference to Clark's work, as well as to other recent Western publications in addition to the Hungarian sources, attest to the value of their monograph. Where Hajdu and Pollmann differ with Clark is in their moderate view on the role played by Serbia in the outbreak of the war. In contrast, Clark puts the major onus for the war on Serbia, which he calls a "rogue state" and compares its prewar "expansionist campaign and its brutality to the ethnic cleansing and war crimes of the 1990 wars in the former Yugoslavia." The casus belli for the Great War was the terrorist act carried out at Sarajevo, the provincial capital of Bosnia Herzegovina, which had been a part of Austria since 1908. On June 28, 1914, Gavrilo Princip, a nineteen year-old Bosnian Serb nationalist participating in an act of conspiracy, assassinated the Habsburg heir Archduke Francis Ferdinand and his wife. The assassination led to an international upheaval, the July Crisis, which ended in the outbreak of World War I on July 28, 1914, once the Austro-Hungarian decision makers used the murder as a pretext to launch a war against Serbia.

The authors provide excellent descriptions and analyses of the Austro-Hungarian military plans and the strategies prepared against Serbia. The war was planned as a preventive war pushed by the Chief of the General Staff Conrad von Hötzendorf. The only decision maker in the Common Ministerial Council who early in July objected to the use of force was the Hungarian Prime Minister István Tisza. The authors, however, stress that Tisza was not against a military solution, which he had already favored in 1913, but that he believed that the timing was not right. 
Pastor, Peter. "Hajdu, Tibor and Ferenc Pollmann. 2014. A régi Magyarország utolsó háborúja 1914-1918 ('The Last War of Old Hungary 1914-1918'). Budapest: Osiris. 415 pp. With maps and photographs." Hungarian Cultural Studies. e-Journal of the American Hungarian Educators Association, Volume 9 (2016): http://ahea.pitt.edu DOI: 10.5195/ahea.2016.247

They emphasize that Tisza "did not object to a war fought following sufficient preparations" ['kellöen elökészitett feltételek mellett megvivandó háború ellen neki sem volt kifogása'] (39). His objection turned into acquiescence when he learned that Germany had already taken steps toward Romania and Bulgaria, which he supported (53). The authors point out that once he made up his mind, his wartime politics were based on a close alliance with Germany (301). The authors' explanation is all the more significant as the present Hungarian regime is eager to shape memory politics in which Tisza is identified as the Great Man in history, one who opposed the war but once it erupted defended the interests of the Hungarian nation. It is in this spirit that the huge Tisza Memorial was resculpted and returned in June 2014 to the square on the northern side of the Parliament Building. The memorial was first consecrated by the revisionist Horthy regime in 1934, then blown up and banished from this location in 1945 when, in the wake of another destructive and lost war, Tisza was perceived as a warmonger responsible for the tragedy of World War I.

Once Tisza was convinced to support the war, Austria-Hungary sent a demarche to Serbia. This act was viewed as an ultimatum and was turned down by Belgrade, which was counting on its Russian patron's support, if war were to come. At the same time, Vienna, believing that Russia was not ready and would not intervene, assumed that the conflict would or could be localized. Evidently, the Serbians knew better. On July 25, 1914, the Monarchy started mobilization against Serbia. The authors provide a detailed explanation of the process of mobilization, as well as of the Monarchy's war plan against Serbia and its later execution. The expert description of the four years of the military's conduct of war, supported by photographs and maps, constitutes another strength of the monograph.

The war against Serbia was declared on July 28, and it was seen as the third Balkan war. Russia mobilized at the end of the next day but, as the authors point out, Austria-Hungary was not ready to fight a two-front war (62). Their implication is that for the Monarchy the war was lost even before it began. Instead of a local war, which because of poor military planning the Monarchy was unable to win, the conflict turned into World War I as the Russian move triggered the members of the bipolar alliance-system into military action. Only Italy stayed out for the time being.

The traditional view about the response to the outbreak of World War I was that the crowds in the belligerent countries welcomed the news in unison. Recent interpretations suggest, however, that this was not the case and that there was considerable popular opposition to the war. Hajdu and Pollmann share in this interpretation in their re-examination of the Hungarian populace's reaction to the declaration of war. They also claim that many who were enthusiastic supporters of the war against Serbia were responding to misleading propaganda that predicted a short, victorious war (69). The war that turned out to be a world conflict was long and the authors trace its history chronologically, covering all its fronts on the continent and naturally emphasizing the ones where Austria-Hungary was fighting. Because World War I became a total war, the home front in Hungary is also a focus of this study, and so is diplomacy. In the home front, the authors point out that there was not only the peaceful mobilization of civilians for production, but also that "the Monarchy conducted a war against its own citizens" ['a Monarchia háborút folytatott saját állampolgárai ellen'] of Ruthenian or Southern-Slav ethnicity. They note that the military courts in Bosnia, Slavonia, and Vojvodina delivered death sentences on a daily basis and that "every politician, intellectual, priest or teacher who was suspected of being a 
Pastor, Peter. "Hajdu, Tibor and Ferenc Pollmann. 2014. A régi Magyarország utolsó háborúja 1914-1918 ('The Last War of Old Hungary 1914-1918'). Budapest: Osiris. 415 pp. With maps and photographs." Hungarian Cultural Studies. e-Journal of the American Hungarian Educators Association, Volume 9 (2016): http://ahea.pitt.edu DOI: 10.5195/ahea.2016.247

Yugoslav patriot was sent to internment camp" ['minden jugoszláv patriotizmussal gyanúsított politikust, intellektuelt, papot, tanítót internálótáborba hurcoltak'] (75).

The demands of the home front soon led to the increased employment of women in industry and by mid-1916 it became twice the prewar number and a quarter of the whole labor force. The authors also point to exploitation of women workers, since these women received lower wages than the fighting men whom they replaced (204). The authors' attention includes sexploitation as well, in that they report the establishment of military bordellos to reduce the incidence of sexually transmitted diseases. For example, they claim that by the spring of 1915 twelve percent of the troops were treated for some form of venereal disease (177). In their examination of the home front, the authors note that the war was financed by regular taxes and war bonds. The Austrian half contributed more to the finances, whereas the Hungarian half invested more in manpower (112-112). In contrast with Austria, the Hungarian parliament held its regular meetings throughout the war and provided sufficient food supplies for the population at large until early 1918, both of which strengthened the public morale. High and popular culture at home likewise contributed to a feeling of normalcy while censorship of opposition newspapers curtailed the spread of bad news.

Hajdu and Pollmann provide a detailed account, accompanied by maps, of the battles on the various fronts and provide statistics for the human losses. For example, the Austro-Hungarian forces in the ill-fated 1914 campaign suffered 273,000 dead or wounded (93). The war with Russia on the Galician front was also being lost; only German assistance saved the AustroHungarian forces from total disaster and from a Russian break-through onto the Hungarian Great Plain and the capture of Budapest. The Russian forces on this front were always superior to the Habsburg forces in firepower and in men (97-98). The human losses at the eastern front were immense during the so-called Carpathian Winter War of 1914-1915 and in 1916, during the Brusilov offensive. As a result, hundreds of thousands of troops fell into Russian captivity. In May 1915 Italy, which had been promised Austro-Hungarian territories by the Entente powers, joined the war on their side and thus caused the opening of a third front for Austria-Hungary (141). The authors therefore name 1916 as the "year of a hopeless deadlock" ['A reménytelen patthelyzet éve'] (179) on the fronts and they describe this year's battles in detail to prove their point. The year 1917, on the other hand, brought about hopes of victory. In March 1917 revolution shook the Russian home front and Russia's troops left the war front in droves. This revolution was followed by a second one in November, and this time the Bolsheviks took over governing in Petrograd and called for peace negotiations, which began in December 1917 at Brest-Litovsk. In response to the specter of a Central Power victory and a possible German global domination, the United States declared war on Germany in April 1917. In December this act was followed up by a belated declaration on Austria-Hungary as well. By then it had become obvious to the Allies, as the Entente alliance was now called, that the Habsburg Monarchy could not be peeled off from its German ally.

The peace negotiations at Brest-Litovsk in January and February 1918 between the representatives of Soviet Russia and of the Central Powers, meaning Germany, Austria-Hungary, Turkey and Bulgaria, foreshadowed the harsh demands to come at the 1919 Paris Peace Conference. In Paris it was the turn of the victorious Allied Powers to dictate charthaginian peace terms to the defeated countries. The Central Powers at the Brest-Litovsk negotiations recognized the independence of a former part of the Russian State, the Ukraine, and signed a 
Pastor, Peter. "Hajdu, Tibor and Ferenc Pollmann. 2014. A régi Magyarország utolsó háborúja 1914-1918 ('The Last War of Old Hungary 1914-1918'). Budapest: Osiris. 415 pp. With maps and photographs." Hungarian Cultural Studies. e-Journal of the American Hungarian Educators Association, Volume 9 (2016): http://ahea.pitt.edu DOI: 10.5195/ahea.2016.247

separate peace treaty with its government called the Rada. The authors point out that the Ukrainians came to the negotiations with demands for Eastern Galicia and Hungarian Subcarpathia (302). Their claims were rejected outright by the Austro-Hungarian foreign minister. At any rate, this was the first instance when a neighbor state demanded Hungarian lands at a World War I peace parley. The second wartime peace conference took place in Bucharest in May 1918. Defeated Romania, which had entered the war in the middle of 1916 on the Allied side in return for gaining Transylvania from Hungary and lands from Bulgaria, was forced to sign a harsh peace treaty. Upon the demands of István Tisza, Hungary received a few thousand square kilometers of Carpathian mountain territories as "strategic frontier adjustments," a rationale which the authors term "grotesque" (307).

While the military situation in 1917 looked promising, the Hungarian home front was showing serious fissures. In parliament Count Mihály Károlyi was calling for the end of the alliance with Germany and for peace negotiations. In November 1917 the 1867 Compromise, which had been renewed in 1907 for ten years, was now extended for two more years with the parliament's proviso that no concessions would be given to the nationalities (259). Outside parliament there were strikes by dissatisfied workers, but the authors note that "the great loser of the war was the urban middle class....The wages were not kept up with the rate of inflation and privation led to loss of prestige and weakening of social status" ['A háború nagy vesztese azonban a városi középosztály volt....Bérük nem tartott lépést az inflációval, s a szükölködés addigi presztizsük, társadalmi sátusuk megrendülésével járt'] (255).

The wartime deprivations also led to increasing political anti-Semitism. According to the authors, however, "this did not impact government policies but the [anti-Semitic] organizations and [their] press were pointedly preparing for their increasing postwar role and following the revolutions these formed the strongest foundation of the counterrevolutionary regime" [' $a$ kormánypolitikára nem volt hatása, de szervezetei és sajtója tudatosan készültek a háború utáni nagyobb szerepvállalásra és a forradalmak után létrejövö ellenforradalmi rendszer bázisának legerösebb elemét alkották'] (257). This interpretation negates a popular postwar argument that is still voiced by the right, and even by some Hungarian historians, that Hungarian anti-Semitism was a response to the three-month dictatorship of the 1919 Hungarian Soviet Republic, which had a top leadership composed predominantly of men of Jewish origin. The revolutions in Hungary came as a consequence of a lost war. Military defeat was already in the air by mid-1918 as on the Balkan front Bulgaria and Turkey were barely holding on against the Allies, while on the Italian front Austria-Hungary was unable to bring about a decisive victory. On the western front Germany was unable to achieve a breakthrough as fresh American troops were tipping the balance in favor of the enemy. The June 1918 Austro-Hungarian offensive on the Piave against the Italian forces was unsuccessful and it became obvious that the bells were tolling for the Monarchy and its army. This campaign brought about serious casualty rates, as did the subsequent attacks. There was a real scarcity of food supplies for the troops, which caused famine conditions (344). The bad news from the front were accompanied by mass desertion and the chief inspector of the Hungarian gendarmerie estimated that hundreds of thousands of troops left their posts (319). The authors also note that while the millions of dead and wounded could be given in figures, no such accounting is possible for those who suffered from shell shock or what was later termed as Posttraumatic Stress Disorder (PTSD). The authors therefore attribute "the cruelties of the revolution and counterrevolution to a considerable extent to the neurosis acquired 
Pastor, Peter. "Hajdu, Tibor and Ferenc Pollmann. 2014. A régi Magyarország utolsó háborúja 1914-1918 ('The Last War of Old Hungary 1914-1918'). Budapest: Osiris. 415 pp. With maps and photographs." Hungarian Cultural Studies. e-Journal of the American Hungarian Educators Association, Volume 9 (2016): http://ahea.pitt.edu DOI: 10.5195/ahea.2016.247

on the battlefield" ['Forradalom és ellenforradalom kilengéseiben nem kis szerepet játszott a harcmezön szerzett neurózis'] (360).

Mutinies occurred among former POW troops who were being repatriated from the Russian camps and who objected to being sent straight to the Italian front. The authors point out that those Hungarian POWs who were still in Soviet Russia in camps along the Trans-Siberian Railway joined the Red Army following the May 25, 1918 uprising of the sixty-thousand strong anti-Bolshevik Czecho-Slovak legion that consisted of former Czech and Slovak POWs of the Austro-Hungarian army. The Hungarians, also about sixty thousand in number, "acted out of self-preservation as the legion had cruelly hunted them down" ['már csak önvédelemböl is, mert a légió kegyetlenül üldözte a magyarokat'] (306). Before the collapse of communism in 1989, official Hungarian historiography insisted that the Hungarians had joined the Reds out of ideological conviction. The authors' explanation is closer to the truth. It indicates that in 1918 in far-away Siberia the former comrades in arms of the Dual Monarchy engaged in an ethnic civil war against each other. They also point out that the legion's moves were seen by the Allies only as anti-communist actions, hence contributing to the favorable reception of Czechoslovak demands at the Paris Peace Conference (307).

On October 17, 1918, former Prime Minister Count István Tisza admitted in the Hungarian parliament that the war was lost. By then the Italian front was collapsing and the troops of various nationalities were returning home, often with arms in their hands. Looting was an everyday occurrence. The home front also collapsed and the authors note that on October 31 , 1918, "of all the possessions of the [Habsburg] Monarchy Hungary was the last to experience revolution... and the only one where the national forces were unable to coalesce in unity" ['Magyarországon tehát a Monarchia országai közül utolsónak gyözött a forradalom,...az egyetlen ország voltunk a térségben, ahol a nemzeti erök még az összeomlás napjaiban sem tudtak összefogni'] (382).

The book ends with a discussion of the Padua Armistice signed on November 3, 1918, between the Allies and the Dual Monarchy. By then the representatives of the defeated armed forces signed in the name of the defunct Habsburg Empire. Since World War I officially ended with peace treaties, it is unfortunate that the authors decided not to add to the monograph a last chapter on the Hungarian aspect of the 1919 Paris Peace Conference and the terms of the Trianon peace treaty. Of course it is also true that by the time the conference opened, it was the "New Hungary" that had to carry the burdens of the lost war. As far as "Old Hungary's Last War" is concerned, the authors of this book succeeded in offering a superb study of the Great War. It is unlikely that this volume will be bested by other Hungarian scholars and for this reason it has the makings of a classic. 